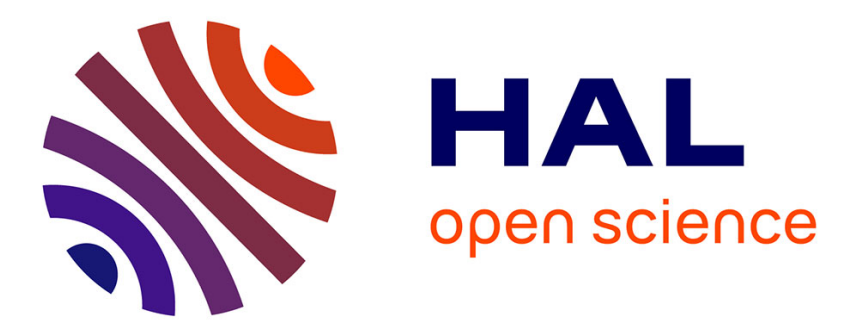

\title{
No recovery of campo rupestre grasslands after gravel extraction: implications for conservation and restoration
}

\author{
Soizig Le Stradic, Geraldo Wilson Fernandes, Elise Buisson
}

\section{To cite this version:}

Soizig Le Stradic, Geraldo Wilson Fernandes, Elise Buisson. No recovery of campo rupestre grasslands after gravel extraction: implications for conservation and restoration. Restoration Ecology, 2018, SEED DISPERSAL AND SOIL SEED BANKS - PROMISING SOURCES FOR ECOLOGICAL RESTORATION, 26 (S2), pp.S151-S159. 10.1111/rec.12713 . hal-01927831

\section{HAL Id: hal-01927831 \\ https://hal.science/hal-01927831}

Submitted on 20 Nov 2018

HAL is a multi-disciplinary open access archive for the deposit and dissemination of scientific research documents, whether they are published or not. The documents may come from teaching and research institutions in France or abroad, or from public or private research centers.
L'archive ouverte pluridisciplinaire HAL, est destinée au dépôt et à la diffusion de documents scientifiques de niveau recherche, publiés ou non, émanant des établissements d'enseignement et de recherche français ou étrangers, des laboratoires publics ou privés. 


\title{
No recovery of campo rupestre grasslands after gravel extraction: implications for conservation and restoration.
}

Running title: No recovery of campo rupestre grasslands

Soizig Le Stradic ${ }^{1,2,3}$, G. Wilson Fernandes ${ }^{2}$, Elise Buisson ${ }^{1}$

${ }^{\mathbf{1}}$ Institut Méditerranéen de Biodiversité et d'Ecologie marine et continentale (IMBE),

Université d'Avignon et des Pays de Vaucluse, UMR CNRS IRD Aix Marseille Université,

IUT site Agroparc, BP 61207, 84911 Avignon cedex 09, France.

${ }^{2}$ Universidade Federal de Minas Gerais, Instituto de Ciências Biológicas, Belo Horizonte, Minas Gerais, Brazil.

${ }^{3}$ Universidade Estadual Paulista (UNESP), Instituto de Biociências, Departamento de Botânica, Rio Claro, São Paulo, Brazil

Corresponding author: soizig.lestradic@gmail.com

\section{Author contributions}

SLS, EB designed the study; SLS collected data: plant survey, soil sampling and seed bank assessment; SLS performed the data analyses and wrote the manuscript; SLS, EB, GWF contributed to revising the manuscript.

\begin{abstract}
Old-growth grasslands, including savannas and tropical grasslands, need centuries to assemble; they are therefore expected to have low resilience to anthropogenic activities that disturb the soil (e.g. cultivation, quarrying, mining, etc.). Understanding which parameters restrict the natural recovery of degraded ecosystems is a major prerequisite for planning an
\end{abstract}


effective restoration program. This study was designed to evaluate the recovery of an oldgrowth grassland, the campo rupestre, after a major disturbance: gravel extraction. In 2010 (i.e. eight years after the degradation), we analyzed soil characteristics, seed bank and vegetation composition in degraded sites consisting of sandy or stony substrates, as well as in reference sites of sandy and stony grasslands. At degraded sites, soils contained lower concentrations of the main nutrients, and seed banks consisted mainly of non-target species. Seed banks in reference grasslands were poor in species and in seeds. Eight years after the degradation, plant communities at degraded sites were still very different from those at the reference sites, presenting ruderals and almost no target species. Altered soil conditions, low propensity of campo rupestre species to form seed banks, and the probable restriction of seed dispersal from the target species in nearby campo rupestre considerably limits the establishment of campo rupestre plant communities in degraded areas. Time is essential for old-growth grassland assemblage and, even with the presence of a propagule source in the surroundings, the assembly of campo rupestre plant communities in degraded sites will take centuries. Therefore, human intervention is necessary to rapidly reestablish the main species.

Key words: tropical grassland restoration, quarrying, seed bank, regeneration, rupestrian grasslands, resilience

\section{Implication for practice}

- Old growth campo rupestre grasslands degraded by gravel exploitation did not recover any of their original characteristics, not even percentage of vegetation cover; human intervention is therefore necessary to rapidly reestablish the dominant species.

- Seed banks in pristine old-growth reference campo rupestre grasslands are poor in seeds and species, suggesting a low probability that bulk topsoil transfer would be effective in reestablishing campo rupestre vegetation in degraded areas. 
- The likely restricted dispersal of target species from nearby reference ecosystems severely limits the establishment of campo rupestre plant communities in degraded areas and implies that restoration projects must reintroduce species. 


\section{Introduction}

Old-growth grasslands, including savannas and tropical grasslands, are species-rich ecosystems whose assembly develops over centuries (Bond \& Parr 2010; Parr et al. 2014; Veldman et al. 2015a). Old-growth grassland communities are resilient to the disturbances they have evolved with, such as fires or herbivory by native fauna (Veldman et al. 2015a). Due to the lengthy duration of their assembly, these plant species rarely succeed at establishing from seed, and their ability to colonize is poor (Veldman et al. 2015a); they are therefore expected to have low resilience to strong and intrusive exogenous disturbances (sensu McIntyre and Hobbs, 1999) and destruction, such as tilling (prior to cultivation), road construction, gravel extraction or mining.

Old-growth grasslands are often degraded or interspersed with recent anthropogenic grasslands. Nevertheless, they are usually neglected in global conservation and restoration programs (Parr et al. 2014; Bond \& Parr 2010; Bond 2016; Veldman et al. 2015a, 2015c), despite their high biodiversity and numerous ecosystem services (Parr et al. 2014; Veldman et al. 2015b), which include a crucial role in water recharge (Honda \& Durigan 2016; Fernandes 2016). Because they are situated in regions currently affected by increasing anthropogenic activities, such as urbanization, mining operations, land use changes and afforestation (Veldman et al. 2014, 2015c; Fernandes et al. 2016), initiatives to conserve and to restore oldgrowth grasslands are urgently needed. However, the dearth of knowledge about old-growth grasslands' resilience to strong anthropogenic disturbances presents a challenge to implementation of efficient conservation and restoration projects and jeopardizes their success.

Assessment of the natural resilience, i.e. both resistance and recovery (sensu Hodgson et al., 2015), of an altered ecosystem should help to determine whether active restoration is necessary and should provide useful information for planning adequate restoration actions 
(Bradshaw 2000; Prach \& Hobbs 2008; Prach \& Walker 2011). System recovery is possible only if the system resists disturbance within its limits. If the system is disturbed beyond tipping points, however, recovery may then require modifications of the physical environment or manipulation of the vegetation (Whisenant 1999). Vegetation recovery will be slow or absent when alteration of the soil's chemical and physical properties generates inappropriate abiotic conditions at the degraded site (i.e. limited nutrient availability, low water availability) (Wong 2003; Yuan et al. 2006). Road construction or roadside gravel extraction, for example, alters abiotic conditions (Barbosa et al. 2010).

Depending on the intensity of the disturbance, the vegetation and the seed bank in the incumbent soil can be either destroyed or severely altered. The lack of target species in the remaining seed bank or among surviving individuals (Wilson 2002; Bakker \& Berendse 1999; Bakker et al. 1996) also delays vegetation recovery. In the absence of an internal species pool, the seed supply for the recovery of degraded areas depends mainly on seed dispersal from surrounding sites via the seed rain (Campbell et al. 2003; Shu et al. 2005; Bakker et al. 1996). However, grassland species may disperse poorly and at a low rate (Oster et al. 2009; Bischoff 2002 ); in such cases, the natural recovery process of species-rich grasslands is very slow (Buisson et al. 2006). Finally, although spontaneous recovery can occur, especially where environmental conditions are moderate (Prach et al. 2007; Prach \& Hobbs 2008), is it probable in cases of strong anthropogenic degradation of old-growth grassland species?

Campos rupestres are old-growth grassland (Veldman et al. 2015a; Fernandes 2016), considered as OCBILs (old climatically-buffered infertile landscapes) (Silveira et al. 2016) and part of the Cerrado domain. They occur between $800 \mathrm{~m}$ to $2000 \mathrm{~m}$ altitude, primarily along the Espinhaço mountain range in south-eastern Brazil. Campos rupestres surround headwaters of important watersheds in Brazil (Callisto et al. 2016) and sustain a huge biodiversity (Silveira et al. 2016). Whereas seed bank and seed rain generally play a main role 
in ecological restoration, little is known about the seed bank or seed rain of Brazilian grasslands, including campo rupestre (but see Medina \& Fernandes 2007), and information about campo rupestre recovery is scarce. Thus, nothing is known about the reliability of residual seed bank or seed dispersal to recover campo rupestre vegetation after a major anthropogenic disturbance.

In this study, we assess campo rupestre vegetation recovery after an anthropogenic disturbance: gravel extraction. As with other old-growth grasslands, we expect campo rupestre recovery to be very slow. To ascertain whether site conditions or low dispersion of target species favor or hamper spontaneous recovery of degraded areas, we compare soil conditions, seed bank and vegetation composition in two co-occurring undisturbed herbaceous reference communities of campo rupestre presenting different soil types-stony and sandy grasslands - and situated within two types of degraded area: one with sandy substrate and one with stony substrate.

\section{Methods}

\section{Study area}

The study took place in the southern portion of the Espinhaço Range, approximately $100 \mathrm{~km}$ northeast of Belo Horizonte, in the state of Minas Gerais, Brazil (19 $15^{\prime}-25^{\prime} \mathrm{S}$ and $\left.43^{\circ} 30^{\prime}-40^{\prime} \mathrm{W}\right)$. The study area is within the Environmental Protected Area of Morro da Pedreira, the buffer zone of the Serra do Cipó National Park. Campos rupestres are composed of a mosaic of species-rich primary grasslands and scattered rocky outcrops with evergreen shrubs and sub-shrubs (Giulietti et al. 1997; Le Stradic et al. 2015a; Silveira et al. 2016) They represent the main vegetation type in the region. Their high plant biodiversity comprises 14.7 $\%$ of the entire Brazilian vascular flora and includes numerous endemic species (Giulietti et al. 1997; Echternacht et al. 2011; Silveira et al. 2016; Fernandes 2016). Campos rupestres are 
fire-prone ecosystems (Le Stradic et al. 2017), but they are not grazed. They are constrained ecosystems with shallow, nutrient-poor and highly acidic soils (Benites et al. 2007; Le Stradic et al. 2015a) and a five-month dry season with significant water shortage. Both sandy and stony grasslands are the main herbaceous communities in the campos rupestres of the study area (Le Stradic et al. 2015a); we therefore consider these two grassland types as the reference ecosystem.

The study area presents a seasonal tropical altitudinal climate, with an annual average temperature of $21.2{ }^{\circ} \mathrm{C}$ (Madeira \& Fernandes 1999). The average annual rainfall is ca. 1622 mm, mainly concentrated during the rainy season between November and April. The dry season extends from May to October (Madeira \& Fernandes 1999).

In 2002, the road MG010 was asphalted, a process during which small quarries were exploited for soil, sand and gravel extraction and were also used to park machinery. Vegetation and upper soil horizons were destroyed. This degradation was not followed by restitution of the soil horizons, leaving the soils altered and composed of several kinds of substrate, including sandy and stony substrate. These degraded areas are surrounded by reference campo rupestre.

To evaluate the recovery of campo rupestre vegetation following such anthropogenic degradation, we analyzed soil characteristics, seed bank composition and vegetation composition in 2010 (eight years after the last degradation in 2002), at six degraded sitesthree sites consisting of sandy substrates (DSa) and three of stony substrate (DSt) - and in ten reference areas: five sandy grasslands ( $\mathrm{Sa})$ and five stony grasslands $(\mathrm{St})$.

Soil samples

To assess soil characteristics, we randomly collected three soil samples from each of the six degraded sites and from each of the ten reference grasslands, once during the wet season (February) and once again during the dry season (July) ( $\mathrm{n}=2$ seasons $\times 3$ samples $\times$ 
16 sites). Each soil sample consisted of three pooled sub-samples taken within an area of around $1 \mathrm{~m}$ in diameter, at $10-\mathrm{cm}$ depth, using a hand trowel. Samples were dried and sieved through a 2-mm mesh sieve prior to analysis. On the fine fraction $(<2 \mathrm{~mm})$, we performed chemical soil analyses (i.e. total $\mathrm{N}, \mathrm{P}, \mathrm{K}, \mathrm{pH}$, organic $\mathrm{C}, \mathrm{Mg}^{2+}, \mathrm{Ca}^{2+}, \mathrm{Al}^{3+}$ ): Phosphorus (P) and Potassium $(\mathrm{K})$ in $\mathrm{mg} / \mathrm{dm}^{3}$; Nitrogen $(\mathrm{N})$ and Organic Carbon $\left(\mathrm{C}_{\mathrm{org}}\right)$ in dag/kg; Magnesium $\left(\mathrm{Mg}^{2+}\right)$, Aluminum $\left(\mathrm{Al}^{3+}\right)$, and Calcium $\left(\mathrm{Ca}^{2+}\right)$ in cmolc/dm ${ }^{3} . \mathrm{P}, \mathrm{N}$ and $\mathrm{K}$ were analyzed with the Mehlich 1 extraction method; $\mathrm{Ca}^{2+}, \mathrm{Mg}^{2+}, \mathrm{Al}^{3+}$ with $1 \mathrm{~mol} / \mathrm{L} \mathrm{KCl}$ extraction; and $\mathrm{C}_{\text {org }}$ followed the Walkley-Black method. Analyses were conducted at the soil laboratory of Viçosa Federal University, Viçosa, Minas Gerais, Brazil. Soil analysis followed the recommendations of EMBRAPA (1997).

\section{Seed banks}

To evaluate seed banks, we randomly collected five 1-liter soil samples from each of the six degraded sites and each of the ten reference grasslands $(n=5$ samples $\times 16$ sites $)$ at the end of the dry season (September); fruit production peaks between April and July (personal observation). Each sample consisted of ten pooled sub-samples, randomly collected within an area of around $2 \mathrm{~m}$ in diameter, at 5-cm depth to overcome seed bank heterogeneity, using a hand trowel. Samples were washed with water on sieves with $4-\mathrm{mm}$ and $200-\mu \mathrm{m}$ mesh sizes to remove 1) plant fragments and stones and 2) the finest soil fraction (clay and silt), respectively. The remaining seed-bearing soil was spread in a thin layer on trays $(25 \mathrm{~cm} \times 35$ $\mathrm{cm}$ ) on compresses placed over a 3-cm thick layer of vermiculite (a neutral substrate). Control trays $(n=3)$ (made of compresses over vermiculite) and controls of the finest soil fraction $(<200 \mu \mathrm{m})(\mathrm{n}=3)$ (made of the finest fraction spread out on compresses over vermiculite) were also prepared in order to 1) control which species could colonize the greenhouse and contaminate samples and 2) ensure that no seed $<200 \mu \mathrm{m}$ was lost by sieving. No germination was found in the finest soil fraction or in any of the control trays. All trays were kept in a 
greenhouse, were regularly moved, and were watered every two days. On a weekly basis, emerging seedlings were identified and removed, or were replanted in pots for later identification. This was done to minimize competition within the trays and to reduce susceptibility to the emission of allelopathic substances. We monitored seed germination until one month passed with no new emergences. We then dried and lightly plowed the samples before initiating a second germination period; this procedure is a well-known technique for stimulating additional germination (Roberts 1981).

\section{Vegetation survey}

We compared the plant community composition of the degraded sites to that of the reference grasslands. In January 2010, we surveyed the vegetation in three sandy (Sa) and three stony (St) reference grasslands, as well as in the six degraded sites (DSa and DSt). Sixteen plots in Sa, St and DSa, and twenty-four plots in DSt were surveyed to record (1) the list of species and (2) the percent cover of each species, visually estimated from the vertical projection of all aerial plant parts. The plots at all sites measured $40 \mathrm{~cm} \times 40 \mathrm{~cm}\left(0.16 \mathrm{~m}^{2}\right)$. Further in the manuscript, we consider the target species-all species occurring in reference grasslands - and non-target species, which occur in degraded areas but not in the reference campo rupestre. The latter group includes ruderal species that commonly grow in altered areas and along roadsides.

\section{Statistical analysis}

To compare soil chemical composition between the different types of soil substrate and between seasons, we performed two-way ANOVAs for each chemical element. For $\mathrm{Al}^{3+}$, we checked normality and variance homogeneity and applied the log transformation (Sokal \& Rohlf 1998). To test for differences among soil substrate and between seasons, TukeyHSD post-hoc tests were performed using values from each season separately when seasonal 
difference was considerable, and using all values (i.e. data from the two seasons pooled together) when there was no significant seasonal difference.

We ran generalized linear mixed models (glmer in the R package lme4) with a Poisson error distribution, a log-link function, and random effect for sites (Crawley 2007) to compare the species richness and the number of emerged seeds in the seed banks of the different areas. We calculated a mean dissimilarity matrix, using Jaccard index (meandist in the $\mathrm{R}$ package vegan) based on species presence/absence data, to assess the plant composition dissimilarity between and within the seed banks of DSa, DSt, Sa, and St. We also performed an ANOSIM (anosim in the R package vegan) for analysis of dissimilarities.

We compared the mean vegetation cover in the reference and degraded areas, using Kruskal-Wallis test followed by pairwise comparisons between group levels with Bonferroni corrections. Mean species richness in both the reference grasslands and degraded sites were examined using generalized linear models (GLM) with a Poisson distribution.

Dissimilarities between vegetation composition in the reference grasslands and the degraded sites were assessed using Adonis, an ANOVA-style analysis. Adonis (i.e. Multivariate ANOVA based on dissimilarities) performs a multivariate analysis of variances using distance matrices to test the differences in group means and performs permutation tests to inspect the significance of the differences observed (Oksanen et al. 2016). The Adonis function determines whether the groups consistently differ in their community composition. Adonis analyses were performed using Bray-Curtis dissimilarity to calculate distance matrices based on vegetation data (quadrat $\times$ species abundance matrices); its output values range from 0 and 1 , tending towards 1 as the dissimilarity between plant communities increases (Bray \& Curtis 1957). Non-metric multidimensional scaling (NMDS), which produces an ordination based on a distance or dissimilarity matrix, was used to represent the dissimilarity between reference and degraded areas according to plant composition. 
All statistical analyses were performed in software R Version 3.2.1 (R Core Team 2015), using stats, vegan (Oksanen et al. 2016) and lme4 (Bates et al. 2015) packages.

\section{Results}

\section{Soil characteristics}

Soil composition varied greatly between the reference grasslands and both types of degraded sites (Fig. 1, Table S1). Main nutrient content at the degraded sites was markedly depleted compared to the reference grasslands, where $\mathrm{N}, \mathrm{C}_{\mathrm{org}}, \mathrm{P}$ and $\mathrm{K}$ concentrations were generally higher and soils were more acidic (Fig. 1). Degraded sites showed slightly lower $\mathrm{Al}^{3+}$ values than the reference grasslands, and $\mathrm{Mg}^{2+}$ values were higher in stony grasslands than in the other areas. Degraded stony sites and reference stony grasslands showed a huge variation in $\mathrm{Ca}^{2+}$ content (Fig. 1). $\mathrm{P}, \mathrm{pH}$ and $\mathrm{C}_{\text {org }}$ varied seasonally, with higher $\mathrm{P}$ and lower $\mathrm{pH}$ values during the dry season (Fig. 1, Table S1). Only the P content varied among soils, owing to interactions between soil type and season (Figure 1, Table S1). Coarse fraction in degraded sandy and stony areas did not differ from undisturbed sandy and stony grasslands, respectively (Table S2), and soil structure was mainly conserved among both degraded (Table S2) and reference areas.

\section{Seed bank in reference and degraded areas}

Based on seedling emergence, seed banks in both undisturbed reference grasslands and degraded sites were generally poor in species and in numbers of seeds (Fig. 2). No significant differences were found for species richness between seed banks of reference grasslands and degraded sites (glmer procedure $\mathrm{z}=1.73, \mathrm{p}=0.08$, Fig. $2 \mathrm{a}$ ). Degraded sites had significantly higher numbers of seeds than the reference grasslands (glmer procedure $\mathrm{z}=2.91, \mathrm{p}<0.01$, Fig. $2 b$ ), but the amount of seeds in samples from degraded sites varied widely (from 0 to more 
than 50 seeds), which made post-hoc tests difficult to interpret (Fig. 2b). Seed bank composition showed high dissimilarity between all sites (ANOSIM statistic R=0.378, $\mathrm{p}<0.001$, Table S3).

\section{Vegetation composition in reference grasslands and degraded sites}

Eight years after the disturbance, degraded sites presented bare ground over more than $70 \%$ of their area, especially the degraded sites with sandy substrate (Fig. 3). Vegetation cover in all degraded sites was significantly lower than in reference grasslands $\left(\square^{2}=147.81\right.$, $\mathrm{p}<0.001$, Fig 3). Species richness in degraded sites was also much lower than in reference grasslands, with less than 5 species per quadrat $(40 \mathrm{~cm} \times 40 \mathrm{~cm})$. In contrast, reference grasslands presented between 12 and 16 species per quadrat (GLM procedure with $\mathrm{p}<0.001$, Fig. 3). Vegetation composition also differed greatly between the reference grasslands and the degraded sites (Adonis $\mathrm{F}=34.36 \mathrm{R}^{2}=0.35, \mathrm{p}<0.01$, Table $\mathrm{S} 4$ ). NMDS was performed to represent the distance matrix in an ordination and illustrate these dissimilarities (Fig. 4). Reference grasslands were quite similar in term of species composition, containing numerous species characteristic of campo rupestre grassland, such as Diplusodon orbicularis, Lagenocarpus alboniger, Mesosetum exaratum, Tatianyx arnacites, Vellozia epidendroides, Xyris pilosa, among others (Fig. 4). Conversely, degraded sites showed greater heterogeneity in term of species composition, with no consistency among substrate type (Fig. 4), and contained ruderal species, including either Andropogon bicornis or Zornia reticulata. A few species found on the reference grasslands-e.g. Polygala paniculata, Declieuxia fruticosa, Chamaecrista papillate, and especially the two Poaceae, Echinolenea inflexa and Mesosetum loliiforme - managed to establish only at the degraded sites with stony substrate (Fig. 4).

\section{Discussion}


The present study demonstrates that campo rupestre did not recover after severe anthropogenic disturbance, despite being particularly resilient to disturbances such as fire (Neves \& Conceição 2010; Le Stradic et al. 2017). Eight years after gravel extraction, bare ground still dominated the degraded sites, and species composition remained very different from undisturbed reference grasslands, despite their presence in the immediate surroundings (within 20-200 m). Some characteristic species from campo rupestre, like Poaceaae (e.g. Tatianyx arnacites, Mesosetum exaratum, Homolepis longispicula), Cyperaceae (e.g. Lagenocarpus rigidus subsp. tenuifolius, Lagenocarpus albo-niger, Bulbostylis paradoxa), Velloziaceaea or Eriocaulaceae, did not recolonize the degraded areas, although large populations of them occurred in adjacent areas (see Le Stradic et al. 2015a). Altered abiotic conditions in degraded sites, a low capacity of campo rupestre plant communities to form seed bank and, probably, a low dispersal ability collectively explain the degraded campo rupestre areas' failure to recover, as detailed hereafter.

\section{Site conditions}

In degraded areas, the depletion of the main soil nutrients, N, P and K, can sometimes hamper vegetation establishment, as they are essential elements for plant growth. In our case, soil structure in degraded areas remained quite similar to those in the reference areas, but gravel extraction severely altered site conditions relative to the reference areas, and soils did not recover after degradation. The reference grasslands are oligotrophic, with low phosphorus and potassium supply (Benites et al. 2007; Silveira et al. 2016; Le Stradic et al. 2015a); hence plant species are already adapted to constrained environmental conditions (Negreiros et al. 2014) - they have developed efficient systems that minimize nutrient loss and optimize resource acquisition, and they are able to accumulate reserves (Oliveira et al. 2016, 2015; Abrahão et al. 2014). We therefore expected plant species from reference grasslands to 
establish, even in sites with non-optimal conditions. Indeed, an experimental restoration project aiming to reintroduce species in a degraded area showed that some campo rupestre shrub species were able to survive and reproduce in these kinds of degraded environments when transplanted there (Gomes et al. 2017; Le Stradic et al. 2014). These species have therefore been identified as potential candidates for restoration projects.

\section{Poor seed banks in reference grasslands}

Seed banks in undisturbed reference grasslands are poor in seeds and species, compared to other campo rupestre habitats such as rocky outcrops or peat bogs (Medina \& Fernandes 2007). In European grasslands, Bekker et al. (1997) noted that species usually associated with poor nutrient conditions were relatively scarce in the seed bank. The fivemonth dry season can also lead to unfavorable environmental conditions for seed bank formation, since wetter sites typically contain a larger number of seeds in mountain communities (Funes et al. 2001; Medina \& Fernandes 2007). Perennial species are dominant in campo rupestre (Le Stradic et al. 2015a; Silveira et al. 2016), indicating that depleted seed banks may also be associated with a low quantity of annuals. However, in German grasslands, Hölzel \& Otte (2004) found that a large proportion of perennial species had a strong tendency for seed accumulation in the soil.

Almost all species in campo rupestre are resprouters after fire (Le Stradic et al. 2017). Those species usually develop specialized underground storage organs (USOs) that securely store carbohydrates (e.g. starch) and water for long periods of time, enabling them to resprout from dormant buds or root systems (Overbeck \& Pfadenhauer 2007; Fidelis et al. 2014; Maurin et al. 2014; Veldman et al. 2015a). While in some cases, resprouters present low seed production and low fecundity in comparison to non-sprouting species (Lamont \& Wiens 2003; Lamont et al. 2011), this is not always true for Cerrado resprouter species. However, it 
has been demonstrated that the seeds of several species in campo rupestre are dormant, unviable or empty (Le Stradic et al. 2015b; Dayrell et al. 2017). Considering all these parameters (i.e. the marked dry season, the large numbers of perennial species, and large number of resprouters), most grassland species from campo rupestre do not seem to form seed banks, though some species produce seeds capable of persisting in soil over time, such as some Velloziaceae (Garcia et al. 2017). We suggest that regeneration via the seed bank is very limited; resprouting remains the primary method of recovery after a disturbance like fire (Le Stradic et al. 2017), and the bud bank may replace the seed bank in these ecosystems (Fidelis et al. 2014) when soils are intact.

\section{Limited seed dispersal}

At degraded sites, the probably small seed banks (see details above) were removed by gravel exploitation. The seeds found in these areas eight years after disturbance thus rely only on seed dispersal from standing vegetation already established on site or from the surroundings. Seed banks in degraded sites present a higher number of seeds in comparison to the reference grasslands, but these seed banks are usually from ruderal species. In campo rupestre, some species do not produce fruits regularly, especially Poaceae species (Le Stradic 2012), which reduces considerably the pool of species able to reach degraded sites. Likewise, seeds of some target species, such as Tatianyx arnacites, Lagenocarpus rigidus subsp. tenuifolius or Rhynchospora riedeliana, occurred sporadically in seed banks of reference grasslands but were absent in the seed banks of degraded sites. Furthermore, eight years after destruction, communities in degraded sites present numerous non-target and ruderal species, but almost no target species despite campo rupestre being a hotspot of biodiversity (Silveira et al. 2016; Fernandes 2016), which implies that dispersal of target species may be very limited. In climate-stable grasslands such as campo rupestre, perennial plants can be 
extremely long-lived and present lower dispersal and colonization potentials (Veldman et al. 2015a; Hopper 2009). The environmental constraints of campo rupestre should favor reduced dispersal to ensure establishment in safe sites (Hopper 2009). In the open physiognomies of campo rupestre, such as sandy and stony grasslands, most species (e.g. Poaceae, Cyperaceae, Xyridaceae, Eriocaulaceae, or Velloziaceae) disperse unassisted, and only a few species produce fleshy fruits that are dispersed mainly by birds (Guerra et al. 2016). Consequently, post-disturbance plant communities are composed largely of non-target and ruderal species, which establish by taking advantage of the soil modifications and high proportion of bare soil (Hobbs \& Huenneke 1992; Le Stradic et al. 2016; Shea \& Chesson 2002; Hansen \& Clevenger 2005). Therefore, a collateral effect of soil modification is the introduction of competition from non-native and/or ruderal species, which may further limit establishment of native species.

Time is definitively fundamental to the assemblage of old-growth grasslands (Veldman et al. 2015a), a fact not often recognized because the evidence of grassland plant longevity is usually underground. Even in conditions that favor establishment, with undisturbed ecosystems in the surroundings acting as sources of propagules, the assembly of plant communities similar to the original ones will take centuries (Veldman et al. 2015a; Redhead et al. 2014; Hirst et al. 2005). In the case of a strong anthropogenic disturbance, it is unlikely that old-growth grasslands will recover by themselves. Rather, human intervention is necessary to rapidly reestablish the main species. Strategies include modification of soil abiotic conditions and the introduction of species through seed sowing, seedling transplantation or vegetation mat translocation. Bulk topsoil transfer allows for the transfer of seeds, propagules and soil microorganisms that are present in the native soil. The technique is commonly used to rehabilitate mines and quarries (Rivera et al. 2012; Koch 2007), but it is more successful in temperate grasslands than in tropical grasslands (Le Stradic et al. 2016). In 
our case, the poverty of the seed bank in reference campo rupestre areas implies that a technique such as bulk topsoil transfer would have limited efficacy in reestablishing campo rupestre herbaceous vegetation in degraded areas, as has been demonstrated for other oldgrowth grasslands (Le Stradic et al. 2016).

\section{Acknowledgements}

We thank Megan King for English revision and Kathrin Kiehl and two anonymous reviewers for their useful comments. S. Le Stradic received postdoctoral support from grant \#2016/13232-5 São Paulo Research Foundation (FAPESP). This work was also supported by the Conselho Nacional de Pesquisa (CNPq) [CNPq 561883/2010-6], by the Société Française d'Ecologie (Bourse de terrain SFE) for seed bank study, RTP CNRS-CEMAGREF "Ingénierie Ecologique" [Ecological Engineering] SAVER - SAVanna Ecological Restoration, Reserva Vellozia, the Ministère Français des affaires étrangères et européennes (EGIDE) [EGIDE 2009/657176K].

\section{References}

Abrahão A, Lambers H, Sawaya ACHF, Mazzafera P, Oliveira RS (2014) Convergence of a specialized root trait in plants from nutrient-impoverished soils: phosphorus-acquisition strategy in a nonmycorrhizal cactus. Oecologia 176:345-355

Bakker JP, Berendse F (1999) Constraints in the restoration of ecological diversity in grassland and heathland communities. TREE 14:63-68

Bakker JP, Poschlod P, Strykstra RJ, Bekker RM, Thompson K (1996) Seed banks and seed dispersal: important topic in restoration ecology. Acta Botanica Neerl. 45:461-490

Barbosa NP de U, Fernandes GW, Carneiro MAA, Junior LAC (2010) Distribution of nonnative invasive species and soil properties in proximity to paved roads and unpaved roads in a quartzitic mountainous grassland of southeastern Brazil ( rupestrian fields ). Biological Invasions 12:3745-3755

Bates D, Mächler M, Bolker B, Walker S (2015) Fitting linear mixed-effects models using lme4. Journal of Statistical Software 67

Bekker RM, Verweij GL, Smith REN, Reine R, Bakker JP, Schneider S (1997) Soil seed banks in European grasslands: does land use affect regeneration perspectives? Journal of Applied Ecology 34:1293-1310

Benites VM, Schaefer ECEGR, Simas FNB, Santos HG (2007) Soils associated with rock outcrops in the Brazilian mountain ranges Mantiqueira and Espinhaço. Communications 


\section{0:569-577}

Bischoff A (2002) Dispersal and establishment of floodplain grassland species as limiting factors in restoration. Biological Conservation 104:25-33

Bond WJ (2016) Ancient grasslands at risk. Science 351:120-122

Bond WJ, Parr CL (2010) Beyond the forest edge: ecology, diversity and conservation of the grassy biomes. Biological Conservation 143:2395-2404

Bradshaw A (2000) The use of natural processes in reclamation - advantages and difficulties. Landscape and Urban Planning 51:89-100

Bray JR, Curtis JT (1957) An ordination of the upland forest communities of southern Wisconsin. Ecological Monographs 27:325-349

Buisson E, Dutoit T, Torre F, Römermann C, Poschlod P (2006) The implications of seed rain and seed bank patterns for plant succession at the edges of abandoned fields in Mediterranean landscapes. Agriculture, Ecosystems \& Environment 115:6-14

Callisto M, Gonçalves JF, Ligeiro R (2016) Water Resources in the Rupestrian Grasslands of the Espinhaço Mountains. In: Ecology and conservation of mountaintop grasslands in Brazil. Fernandes, GW, editor. Springer International Publishing, Switzerland pp. 87102.

Campbell DR, Rochefort L, Lavoie C (2003) Determining the immigration potential of plants colonizing disturbed environments : the case of milled peatlands in Quebec. Journal of Applied Ecology 40:78-91

Crawley MJ (2007) The R Book. John Wiley. Chichester

Dayrell RLC, Garcia QS, Negreiros D, Baskin CC, Baskin JM, Silveira FAO (2017) Phylogeny strongly drives seed dormancy and quality in a climatically buffered hotspot for plant endemism. Annals of Botany 119:267-277

Echternacht L, Trovó M, Oliveira CT, Pirani JR (2011) Areas of endemism in the Espinhaço Range in Minas Gerais. Flora 206:782-791

Fernandes GW et al. (2016) Afforestation of savannas: an impending ecological disaster. Natureza \& Conservação 14:146-151

Fernandes GW (2016) Ecology and conservation of mountaintop grasslands in Brazil. Springer International Publishing, Switzerland

Fidelis A, Appezzato-da-Glória B, Pillar VD, Pfadenhauer J (2014) Does disturbance affect bud bank size and belowground structures diversity in Brazilian subtropical grasslands? Flora 209:110-116

Funes G, Basconcelo S, Díaz S, Cabido M (2001) Edaphic patchiness influences grassland regeneration from the soil seed-bank in mountain grasslands of central Argentina. Austral Ecology 26:205-212

Garcia QS, Saraiva IS, Soares da Mota LA, Bicalho EM (2017) Long-term persistence of Velloziaceae species in the soil seed bank in campo rupestre vegetation, Brazil. Plant Ecology \& Diversity 17550874.2017.1379570

Giulietti A, Pirani J, Harley R (1997) Espinhaço range region: eastern Brazil. In: Centre of plants diversity: a guide and strategy for their conservation. Davis, V, HerreraMacBryde, O, Villa-Lobos, J, \& Hamilton, A, editors. Cambridge p. 397-404.

Gomes VM, Negreiros D, Fernandes GW, Pires AC V., Silva ACDR, Le Stradic S (2017) 8.5 years monitoring of shrub species translocation in degraded Neotropical mountain grassland. Restoration Ecology

Guerra TJ, Carstensen DW, Morellato LPC, Silveira FAO, Costa F V. (2016) Mutualistic Interactions Among Free-Living Species in Rupestrian Grasslands. In: Ecology and conservation of mountaintop grasslands in Brazil. pp. 291-314.

Hansen MJ, Clevenger AP (2005) The influence of disturbance and habitat on the presence of non-native plant species along transport corridors. Biological Conservation 125:249-259 
Hirst RA, Pywell RF, Marrs RH, Putwain PD (2005) The resilience of calcareous and mesotrophic grasslands following disturbance. Journal of Applied Ecology 42:498-506

Hobbs RJ, Huenneke LF (1992) Disturbance, Diversity, and Invasion : Implications for Conservation. Conservation Biology 6:324-337

Hodgson D, McDonald JL, Hosken DJ (2015) What do you mean, 'resilient'? Trends in Ecology \& Evolution 30:503-506

Hölzel N, Otte A (2004) Assessing soil seed bank persistence in flood-meadows : The search for reliable traits. Journal of Vegetation Science 15:93-100

Honda EA, Durigan G (2016) Woody encroachment and its consequences on hydrological processes in the savannah. Philosophical Transactions of the Royal Society B: Biological Sciences 371:20150313

Hopper SD (2009) OCBIL theory: towards an integrated understanding of the evolution, ecology and conservation of biodiversity on old, climatically buffered, infertile landscapes. Plant and Soil 322:49-86

Koch JM (2007) Alcoa's Mining and Restoration Process in South Western Australia. Restoration Ecology 15:11-16

Lamont BB, Enright NJ, He T (2011) Fitness and evolution of resprouters in relation to fire. Plant Ecology 212:1945-1957

Lamont BB, Wiens D (2003) Are seed set and speciation rates always low among species that resprout after fire, and why? Evolutionary Ecology 17:277-292

Madeira J, Fernandes GW (1999) Reproductive phenology of sympatric taxa of Chamaecrista ( Leguminosae ) in Serra do Cipo. Journal of Tropical Ecology 15:463-479

Maurin O et al. (2014) Savanna fire and the origins of the 'underground forests' of Africa. New Phytologist 204:201-214

McIntyre S, Hobbs R (1999) A framework for conceptualizing human effects on landscapes and its relevance to management and research models. Conservation Biology 13:12821292

Medina MBO, Fernandes GW (2007) The potential of natural regeneration of rocky outcrop vegetation on rupestrian field soils in 'Serra do Cipó ', Brazil. Revista Brasileira de Botânica 30:665-678

Negreiros D, Le Stradic S, Fernandes GW, Rennó HC (2014) CSR analysis of plant functional types in highly diverse tropical grasslands of harsh environments. Plant Ecology 215:379-388

Neves SPS, Conceição AA (2010) Campo rupestre recém-queimado na Chapada Diamantina, Bahia, Brasil : plantas de rebrota e sementes, com espécies endêmicas na rocha. Acta Botanica Brasilica 24:697-707

Oksanen J et al. (2016) Vegan: community ecology package. R package version 2.3-3.

Oliveira RS, Abrahão A, Pereira C, Teodoro GS, Brum M, Alcantara S, Lambers H (2016) Ecophysiology of Campos Rupestres Plants. In: Ecology and conservation of mountaintop grasslands in Brazil. Fernandes, GW, editor. Springer International Publishing, Switzerland pp. 227-272.

Oliveira RS, Galvão HC, de Campos MCR, Eller CB, Pearse SJ, Lambers H (2015) Mineral nutrition of campos rupestres plant species on contrasting nutrient-impoverished soil types. New Phytologist 205:1183-1194

Oster M, Ask K, Romermann C, Tackenberg O, Eriksson O (2009) Agriculture , Ecosystems and Environment Plant colonization of ex-arable fields from adjacent species-rich grasslands : The importance of dispersal vs . recruitment ability. Agriculture, Ecosystems and Environment 130:93-99

Overbeck GE, Pfadenhauer J (2007) Adaptive strategies in burned subtropical grassland in southern Brazil. Flora - Morphology, Distribution, Functional Ecology of Plants 202:27- 
49

Parr CL, Lehmann CER, Bond WJ, Hoffmann WA, Andersen AN (2014) Tropical grassy biomes: misunderstood, neglected, and under threat. Trends in Ecology \& Evolution 29:205-213

Prach K et al. (2007) The Role of Spontaneous Vegetation Succession in Ecosystem Restoration: A Perspective. 4:111-114

Prach K, Hobbs RJ (2008) Spontaneous Succession versus Technical Reclamation in the Restoration of Disturbed Sites. Restoration Ecology 16:363-366

Prach K, Walker LR (2011) Four opportunities for studies of ecological succession. Trends in Ecology \& Evolution 26:119-123

R Core Team (2015) R: A language and environment for statistical computing. R Foundation for Statistical Computing,Vienna, Austria.

Redhead JW, Sheail J, Bullock JM, Ferreruela A, Walker KJ, Pywell RF (2014) The natural regeneration of calcareous grassland at a landscape scale: 150 years of plant community re-assembly on Salisbury Plain, UK Fraser, L, editor. Applied Vegetation Science 17:408-418

Rivera D, Jáuregui BM, Peco B (2012) The fate of herbaceous seeds during topsoil stockpiling: Restoration potential of seed banks. Ecological Engineering 44:94-101

Roberts HA (1981) Seed banks in soils. Advances in Applied Biology 6:1-55

Shea K, Chesson P (2002) Community ecology theory as a framework for biological invasions. Trends in Ecology \& Evolution 17:170-176

Shu WS, Ye ZH, Zhang ZQ, Lan CY, Wong MH (2005) Natural Colonization of Plants on Five Lead/Zinc Mine Tailings in Southern China. Restoration Ecology 13:49-60

Silveira FAO et al. (2016) Ecology and evolution of plant diversity in the endangered campo rupestre: a neglected conservation priority. Plant and Soil 403:129-152

Le Stradic S et al. (2016) Comparison of translocation methods to conserve metallophyte communities in the Southeastern D.R. Congo. Environmental Science and Pollution Research 23:13681-13692

Le Stradic S (2012) Composition, phenology and restoration of campo rupestre mountain grasslands - Brazil. Université d'Avignon et des Pays de Vaucluse, France \& Universidade Federal de Minas Gerais, Brazil

Le Stradic S, Buisson E, Fernandes GW (2015a) Vegetation composition and structure of some Neotropical mountain grasslands in Brazil. Journal of Mountain Science 12:864877

Le Stradic S, Buisson E, Negreiros D, Campagne P, Wilson Fernandes G (2014) The role of native woody species in the restoration of Campos Rupestres in quarries. 17:109-120

Le Stradic S, Hernandez P, Fernandes GW, Buisson E (2017) Regeneration after fire in campo rupestre: Short- and long-term vegetation dynamics. Flora - Morphology, Distribution, Functional Ecology of Plants (in press)

Le Stradic S, Silveira FAO, Buisson E, Cazelles K, Carvalho V, Fernandes GW (2015b) Diversity of germination strategies and seed dormancy in herbaceous species of campo rupestre grasslands. Austral Ecology 40:537-546

Veldman JW et al. (2015a) Toward an old-growth concept for grasslands, savannas, and woodlands. Frontiers in Ecology and the Environment 13:154-162

Veldman JW et al. (2015b) Toward an old-growth concept for grasslands, savannas, and woodlands. Frontiers in Ecology and the Environment 13:154-162

Veldman JW et al. (2014) Tyranny of trees in grassy biomes. Science 347:484-485

Veldman JW et al. (2015c) Where Tree Planting and Forest Expansion are Bad for Biodiversity and Ecosystem Services. BioScience 65:1011-1018

Whisenant SG (1999) Repairing damaged wildlands: A process-priented, landscape-scale 
approach. Cambridge University Press

Wilson SD (2002) Chapter 19. Prairies. In: Handbook of ecological restoration. Volume 2. Restoration in practice. Perrow, MR \& Davy, JA, editors. New York pp. 443-465.

Wong MH (2003) Ecological restoration of mine degraded soils, with emphasis on metal contaminated soils. Ecological Restoration 50:775-780

Yuan J, Fang W, Fan L, Chen Y, Wang D, Yang Z (2006) Soil Formation and Vegetation Establishment on the Cliff Face of Abandoned Quarries in the Early Stages of Natural Colonization. Restoration Ecology 14:349-356 

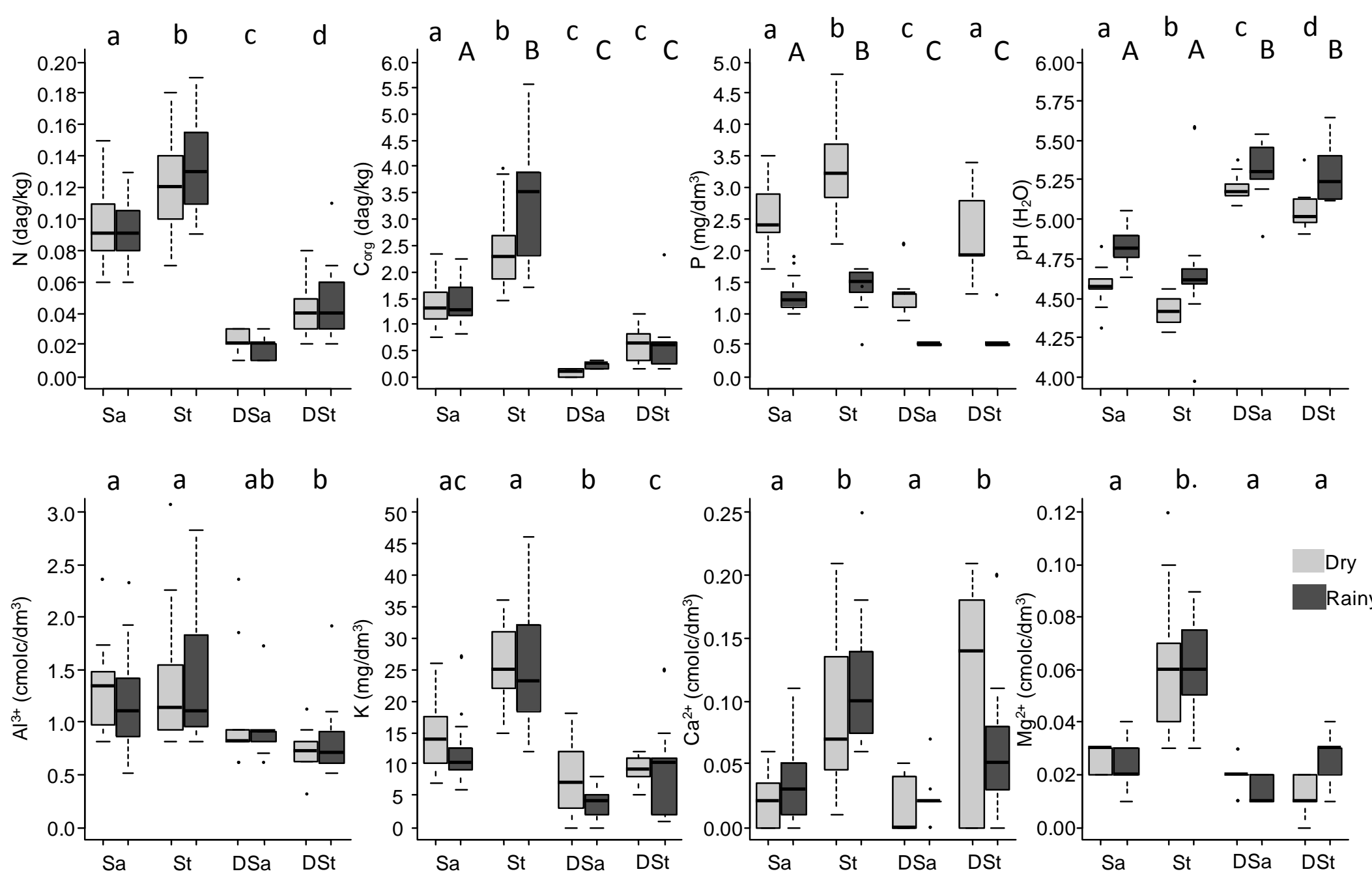

Figure 1: Box-and-whisker plots (including the extreme of the lower whisker, the lower hinge, the median, the upper hinge and the extreme of the upper whisker for each group) of the different chemical soil parameters, from soils collected in 5 sandy grasslands (Sa), 5 stony grasslands 
(St), 3 degraded areas with sandy substrate (DSa) and 3 degraded areas with stony substrate (DSt), during the dry season (light grey) and the rainy season (dark grey). See Table 1 for statistical tests. Letters indicate significant differences according TukeyHSD tests (p < 0.05) performed on pooled values of both seasons when there are no seasonal differences, according to Table S1, and performed on values from each season separately when there are seasonal differences, according to Table S1. In this last case, capital letters are results for the rainy season, and lowercase letters are results for the dry season. 

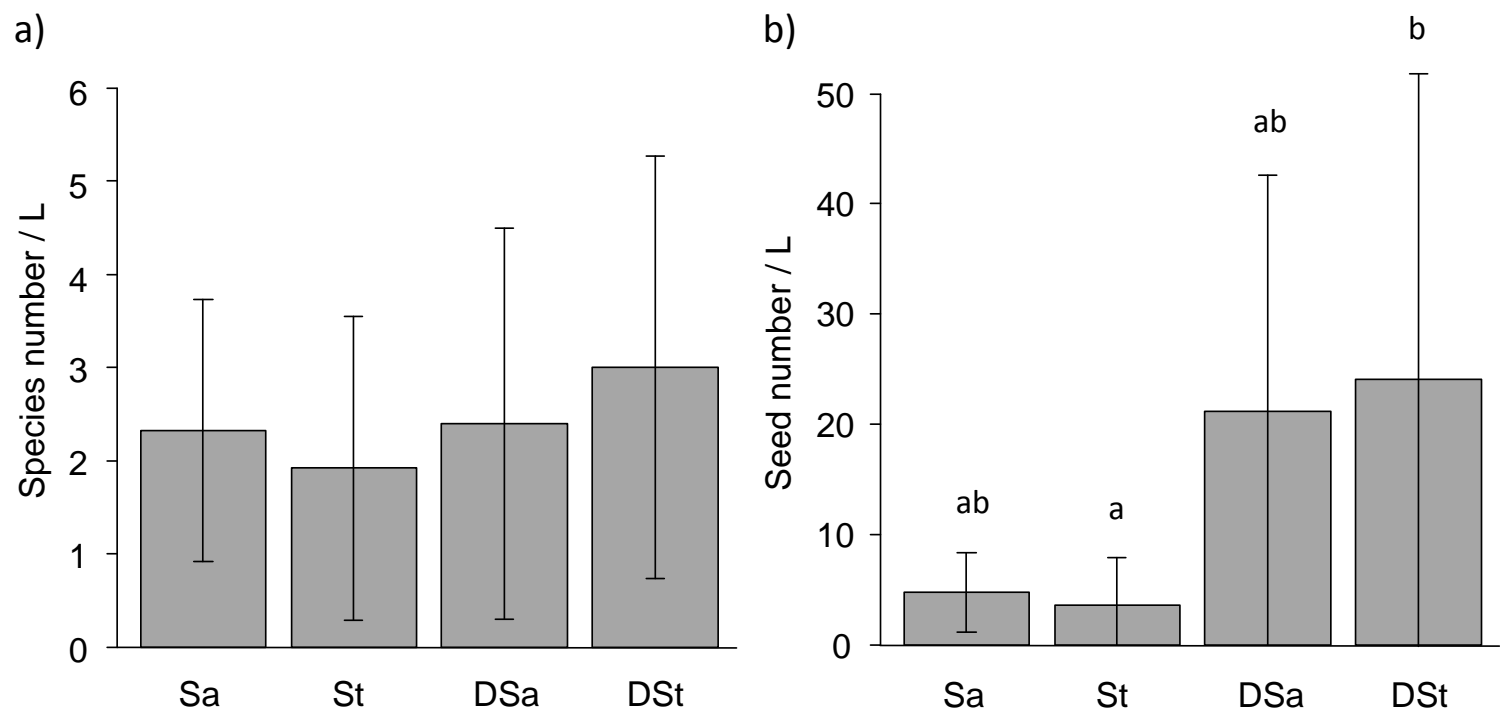

Figure 2: a) Number of species presenting emerged seeds per $1 \mathrm{~L}$ of soil, and b) number of emerged seeds per $1 \mathrm{~L}$ of soil in the seed banks of the reference grasslands (sandy [Sa] and stony [St] grasslands) and the degraded areas (with sandy substrate [DSa] and with stony substrate [DSt]). Different letters indicate significant differences according to the GLM results. Bars stand for standard error. 
a)

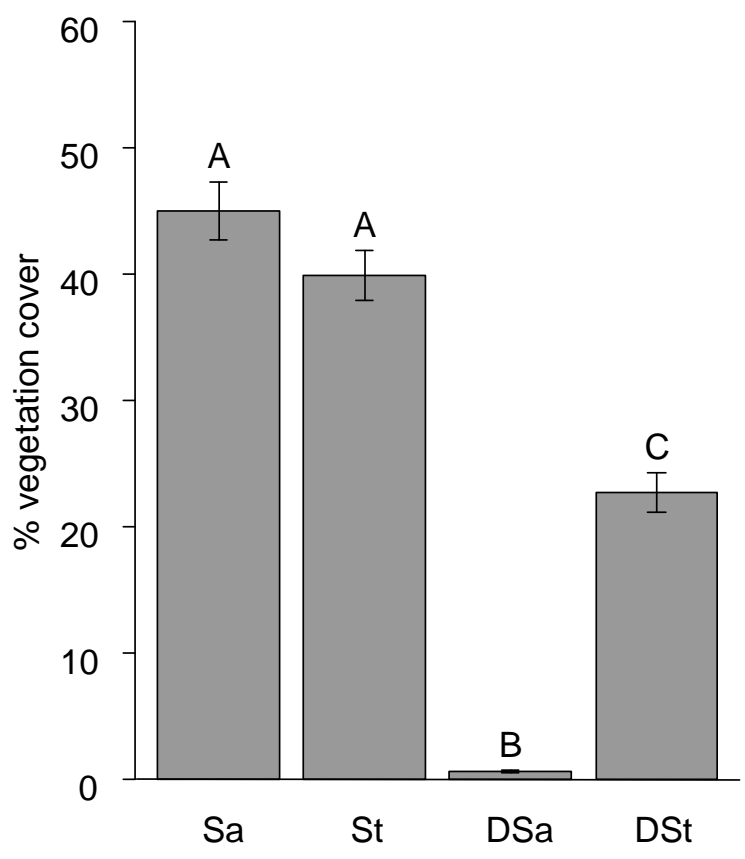

b)

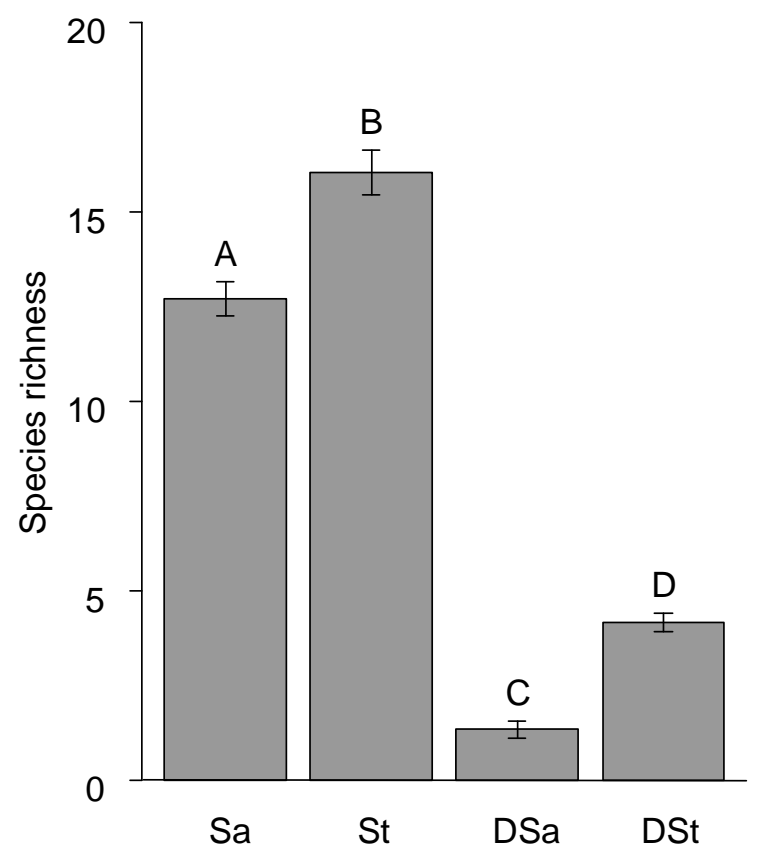

Figure 3: a) Vegetation percentage cover and b) species richness in the reference grasslands (sandy [Sa] and stony [St] grasslands) and the degraded areas (with sandy substrate [DSa] and with stony substrate [DSt]), recorded in $40 \mathrm{~cm} \mathrm{x} 40 \mathrm{~cm}$ plots. Different letters indicate significant differences according to a) the pairwise comparisons and b) the GLM results. Bars stand for standard error. 

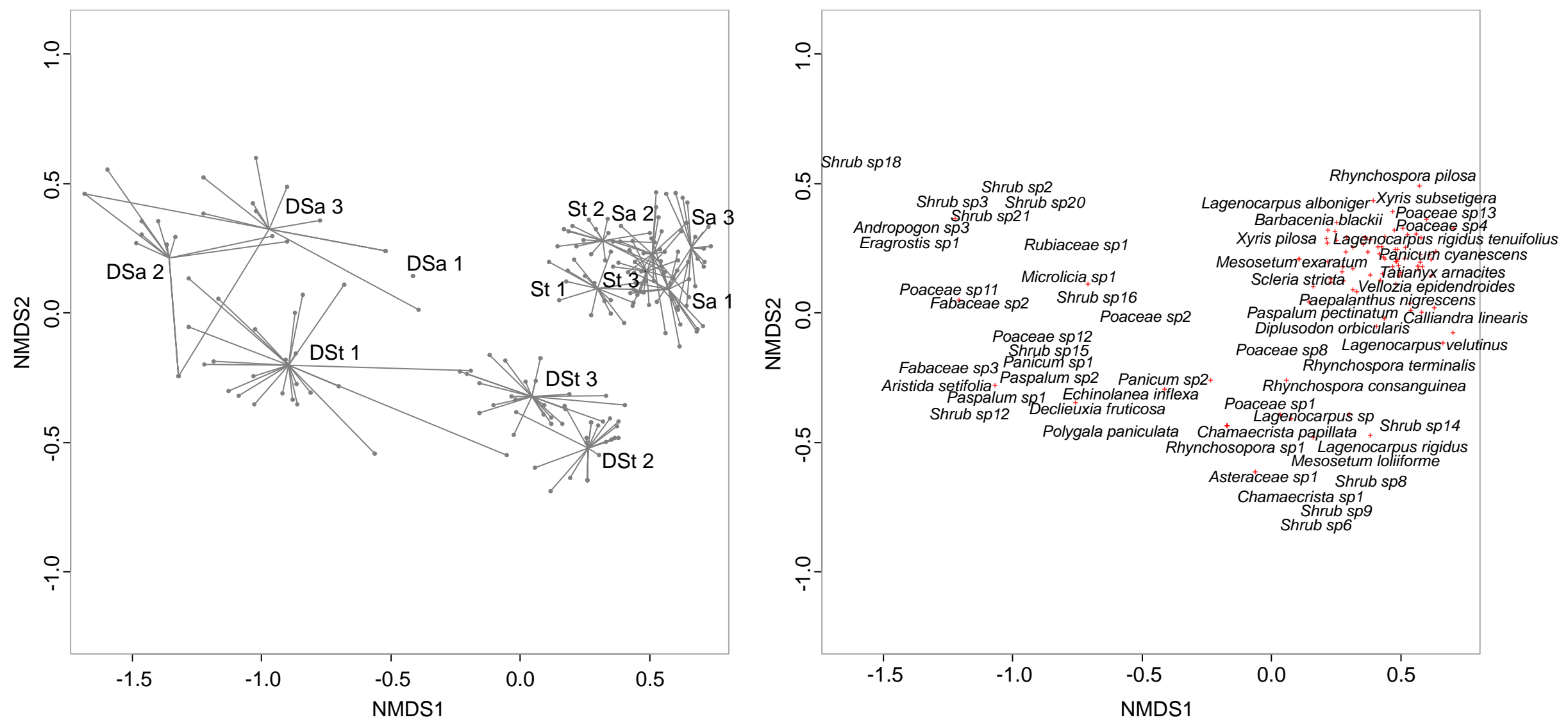

Figure 4: Non-metric multidimensional scaling (NMDS) based on dissimilarity matrix from vegetation survey performed on 216 vegetation plots (40 cm x $40 \mathrm{~cm}$ quadrat) [216 observations $\times 151$ species] in 3 sandy (Sa) and 3 stony reference grasslands (St), in 3 degraded areas with sandy substrate (DSa) and 3 degraded areas with stony substrate (DSt). For clarity, the left graph shows the barycenters of each sampling site, and the right graph shows only the most correlated species. Few points of the site DSa1 are represented because numerous quadrats were vegetation-free. 


\section{Supporting Information:}

Table S1: Results of the two-way ANOVAs performed for chemical soil parameters, according to soil substrate (i.e. sandy grasslands, stony grasslands, degraded sandy substrate and degraded stony substrate), for the two seasons (i.e. wet and rainy season) (n=96). ns: nonsignificant difference, *: significant difference with $\mathrm{P}<0.05$, ***: significant difference with $\mathrm{P}<0.001$.

Table S2: Mean and standard error values of soil texture, according to soil substrate: sandy grasslands, stony grasslands, degraded sandy substrate and degraded stony substrate).

Table S3: Mean dissimilarity matrix (using Jaccard index) of the seed bank composition between the degraded areas with stony substrate (DSt) and sandy substrate (DSa) and reference grasslands: the sandy $(\mathrm{Sa})$ and the stony $(\mathrm{St})$ grasslands, based on the matrix of species presence-absence data. The diagonal gives the averages within classes. Index values closer to 1 indicate greater dissimilarity between seed banks.

Table S4: Mean dissimilarity matrix (using Bray-Curtis index) of vegetation composition between the degraded areas with stony substrate (DSt) and sandy substrate (DSa) and reference grasslands: the sandy $(\mathrm{Sa})$ and the stony $(\mathrm{St})$ grasslands based on the matrix of species percentage cover data. The diagonal gives the averages within classes. Index values closer to 1 indicate greater dissimilarity between seed banks. 